\title{
VOLATILITY OF EXCHANGE RATES IN SELECTED NEW EU MEMBERS: EVIDENCE FROM DAILY DATA
}

\author{
JARKO FIDRMUC \\ ROMAN HORVÁTH
}

\begin{abstract}
CESIFO WORKING PAPER NO. 2107
CATEgory 6: MONETARy POLICY AND INTERNATIONAL FinANCE

OCTOBER 2007
\end{abstract}
An electronic version of the paper may be downloaded
- from the SSRN website:
- from the RePEc website:
- from the CESifo website:
www.SSRN.com
www.RePEc.org
www.CESifo-group.org/wp




\title{
VOLATILITY OF EXCHANGE RATES IN SELECTED NEW EU MEMBERS: EVIDENCE FROM DAILY DATA
}

\begin{abstract}
We examine the daily exchange rate dynamics in selected new EU member states (Czech Republic, Hungary, Poland, Romania, and Slovakia) using GARCH and TARCH models between 1999 and 2006. Despite these countries adopted inflation targeting regime, they occasionally tried to manage their exchange rate. We find that the low credibility of exchange rate management implied higher volatility of exchange rates when it substantially deviated from the implicit target rates for all countries. Finally, we find significant asymmetric effects of the volatility of exchange rates in all analyzed countries.
\end{abstract}

JEL Code: F31, C22, C23.

Keywords: exchange rates, target zones, ERM II, inflation targeting, GARCH.

\author{
Jarko Fidrmuc \\ Department of Economics \\ University of Munich \\ Geschwister-Scholl-Platz 1 \\ 80539 Munich \\ Germany \\ jarko.fidrmuc@Irz.uni-muenchen.de
}

\author{
Roman Horváth \\ Czech National Bank \\ Na príkope 28 \\ 11503 Prague 1 \\ Czech Republic \\ roman.horvath@cnb.cz
}

September 2007

We thank two anonymous referees, Paul de Grauwe, Mikael Bask, Iikka Korhonen, Gunter Schnabl, Zuzana Fungacova, Aaron Mehrota, Matúš Senaj, Juraj Valachy, Bas van Aarle and workshop participants at the CESifo conference on Euro area enlargement, as well as seminar participants at the National Bank of Slovakia and BOFIT for helpful comments. We appreciate research assistance by Mirja Bächle and Yin Xia. The views expressed here do not necessarily represent those of the Czech National Bank. Horváth acknowledges the support from the Czech Science Foundation grant "402/05 H510 Economic Theory of Political Markets". 


\section{Introduction}

All new member states (NMS) of the EU face a trade-off between exchange rate stability and flexibility. The recent literature on optimum currency area (OCA) criteria in the NMS surveyed by Fidrmuc and Korhonen (2006) shows that these countries increasingly constitute an optimum currency area with the EMU. Similarly, Horváth (2007) finds that the NMS fulfill OCA criteria at approximately the same level as the euro area countries before they adopted euro, suggesting that the benefits of exchange rate stability may prevail.

By contrast, the developments especially in Central Europe ${ }^{1}$ showed a process of increasing exchange rate flexibility during the previous decade (see Markievicz, 2006, and Frömmel and Schobert, 2006). This development has been reversed only recently by the first accessions to the Exchange Rate Mechanism II (ERM II) and the starting process of euro adoption in the NMS of the EU. ${ }^{2}$ In the specific conditions of these countries, relatively flexible exchange rate regimes have appeared to be appropriate to deal with the high capital flows, productivity improvements and the appreciation of exchange rates also in nominal terms (see Égert and Lommatzsch, 2004). At the same time, the exchange rate peg was replaced by monetary policies, putting more emphasis on inflation stabilization. Actually, nearly all countries of our sample have adopted different types of inflation targeting. ${ }^{3}$ Still, several NMS have used interventions at the foreign exchange market (see Égert, 2007, Égert and Komárek, 2006, or Geršl and Holub, 2006). On the one hand, these actions were largely motivated by inflation and competitiveness pressures, which in small and open economies heavily depend on

\footnotetext{
${ }^{1}$ On the other hand, several smaller transition economies in South East Europe and in the Baltics have adopted currency boards or comparably fixed exchange rate regimes. This development confirms Eichengreen's (1994) bipolar hypothesis that small and open economies have to decide between the extreme points of exchange rate flexibility.

${ }^{2}$ Estonia, Lithuania and Slovenia joined the ERM II in 2004, while Cyprus, Malta, Latvia and Slovakia followed in 2005. Furthermore, Slovenia introduced the euro by January 2007, while Cyprus and Malta will follow in January 2008.

${ }^{3}$ Czech Republic and Poland adopted inflation targeting in 1998, Romania and Slovakia followed after a period of informal inflation targeting in 2005. Hungary adopted inflation targeting regime in mid-2001 and accompanied it with managed exchange rate with the fluctuation band of $\pm 15 \%$.
} 
exchange rates. On the other hand, this development corresponds also to the fear of floating phenomenon analyzed by Calvo and Reinhart (2002).

These arguments mean that some NMS are likely to pursue a de facto exchange rate policy of implicit target zones around time-varying target exchange rates, ${ }^{4}$ which is similar to the proposal of target zone around a fundamental equilibrium exchange rate proposed by Williamson (1985), Edison et al. (1987), and Chmelarova and Schnabl (2006). Similarly like in Krugman's (1991) exchange rate target zone model, the volatility of exchange rate at the borders of target zones should be smaller than in the area close to the central parity if the regime is fully credible. In the opposite case, we should observe that exchange rate volatility increases with the distance from the target exchange rates. The opposite case is especially appealing for us, as we model the countries that did not adopt official target zones, but rather tried to keep the exchange rates relatively stable.

Furthermore, expectations may be in principle formed differently in the appreciation and depreciation parts of the target zones (either de jure or de facto), which may cause systematic asymmetric effects. This pattern of exchange rate behavior can be estimated by generalized autoregressive conditional heteroskedasticity (GARCH) models. Potential asymmetry in exchange rate volatility is addressed by threshold autoregressive conditional heteroskedasticity (TARCH) models.

The paper is structured as follows. The next section reviews the literature on the exchange rate target zones. Section 3 presents data and Section 4 estimates GARCH models. Finally, Section 5 concludes. Additionally sensitivity results are presented in the appendix.

\section{Related Literature}

A fixed exchange rate regime with a non-zero fluctuation band is generally referred to as a target zone (see for example Ghosh et al., 2003). The motivation for maintaining a target zone exchange rate regime is typically that some flexibility in exchange rate

\footnotetext{
${ }^{4}$ For example, the National Bank of Slovakia declared its official conduct of the monetary policy as "inflation targeting in the conditions of the ERM II" in 2004 (see NBS, 2004). Nell (2004, p. 24) states that "implicit inflation targeting ... is not in conflict with the exchange rate arrangement and has thus far served the NBS rather well".
} 
fluctuations is allowed, while the bands in principle assure an elimination of the eventually excessive fluctuations common under free float exchange rate regime. For a comprehensive survey of this literature, we refer the reader to Kempa and Nelles (1999), Obstfeld and Rogoff (1998), and Sarno and Taylor (2002). Bessec (2003) and Chung and Tauchen (2001) review models with asymmetric and implicit target zones.

Krugman (1991) provides a seminal contribution to an analysis of exchange rate dynamics under target zones. The early naive approach to exchange rate modeling in the target zone assumed that the exchange rate behaves as the free float inside the band and as the fixed exchange rate regime at the edge of the band. In consequence, the fluctuation band has no influence on exchange rate behavior inside the band. However, Krugman (1991) stresses the role of exchange rate expectations and argues that the existence of a credible fluctuation band influences the exchange rate behavior not only at the edge of the band, but also inside the band. Consequently, when the exchange rate is close to the edge of the band, the foreign exchange market participants expect interventions to keep the exchange rate inside the band. As a result, the expected change of the exchange rate is non-zero. It is positive if the exchange rate reaches the weaker side of the fluctuation band, and vice versa. Thus, exchange rate is mean-reverting (this is typically labeled as honeymoon effects in the target zone literature). Besides, the exchange rate becomes completely insensitive to fundamentals at the edges of the band (which is referred to as smooth pasting).

There have been several papers examining the Krugman model empirically. Engle and Gau (1997) examine whether the position of spot exchange rate within the band is associated to its volatility using the data from several EU countries participating in the European Monetary System between 1986 and 1993. They find rather mixed support for the Krugman model, namely only in a few countries the negative relationship between the deviation of the exchange rate from its central parity and the exchange rate volatility is detected. Crespo-Cuaresma et al. (2005a) study exchange rate dynamics in a majority of EU members over different sample periods. Primarily, they test for the so-called effective band within the officially announced band. The motivation is that central banks typically do not wait until the exchange rate hits the official band, but rather start intervening already within the band. Chmelarova and Schnabl (2006) discuss the 
intervention pattern based on Krugman's model in Croatia as compared to developed countries.

Exchange rate volatility in selected NMS is also analyzed by Kočenda and Valachy (2006) and Schnabl (2008). They find that exchange rate volatility generally increased with the introduction of more flexible exchange rate arrangements. Furthermore, the level of interest rates differential decreases exchange rate volatility, while the volatility of interest rates differential has the opposite effect.

\section{Data description}

Our dataset contains the daily euro exchange rates in the Czech Republic, Poland, Romania, Hungary, and Slovakia between January 1997 and May 2007. However, we restrict our data sample to the period starting in January 1999. On the one hand, the starting point of our analysis is determined by the creation of the euro. Thus, we avoid observations characterized by possibly non-standard volatility due to the change-over in the euro area countries. On the other hand, all NMS introduced inflation targeting regime in this period with less emphasis on exchange rate stabilization. These countries also did not experience any currency crisis during the analyzed time. We exclude all countries with currency boards (Bulgaria and the Baltic States) and Slovenia, which introduced the euro in 2007 , from our analysis.

As a result, our analysis concentrates on the daily exchange rates of euro in the Czech Republic, Hungary, Poland, Slovakia, and Romania between January 1997 and May 2007. The implicit target exchange rate is approximated by $240^{\text {th }}$ moving average mode (that is, the average of \pm 120 trading days or approximately one year). ${ }^{5}$ The computation of moving average restricts our estimation period from January 1999 to October 2006, which provides about 2000 observations. $^{6}$

\footnotetext{
${ }^{5}$ Moving average, as the approximation of equilibrium exchange rate, is also adopted by e.g. Ito and Yabu (2007) and Chmelarova and Schnabl (2006).

${ }^{6}$ Alternatively, we use the time variable trend proxied by the Hodrick-Prescott filter (available upon request from authors).
} 
Figure 1: Exchange Rates vis-à-vis Euro, January 1999 to October 2006

Czech Republic

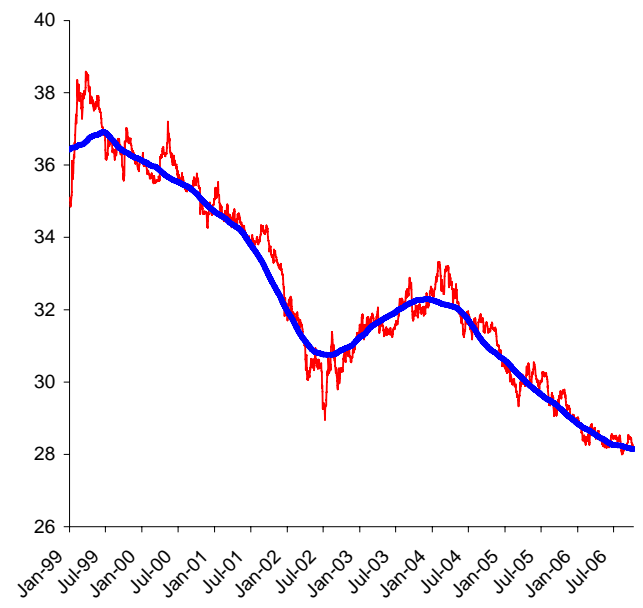

Poland

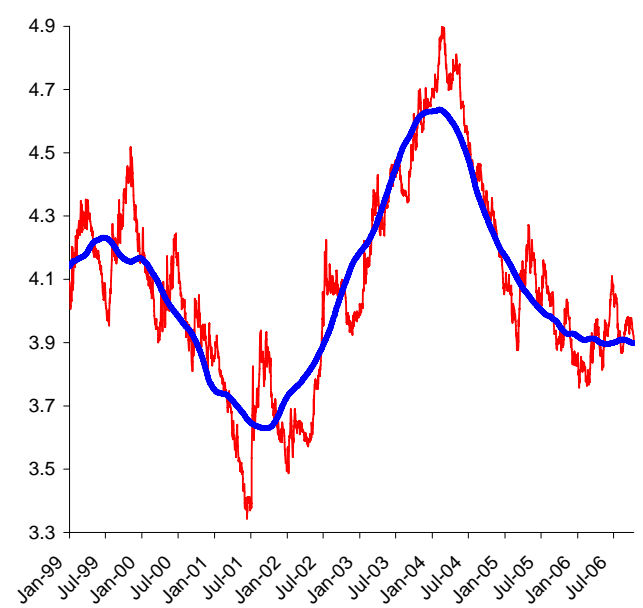

Hungary

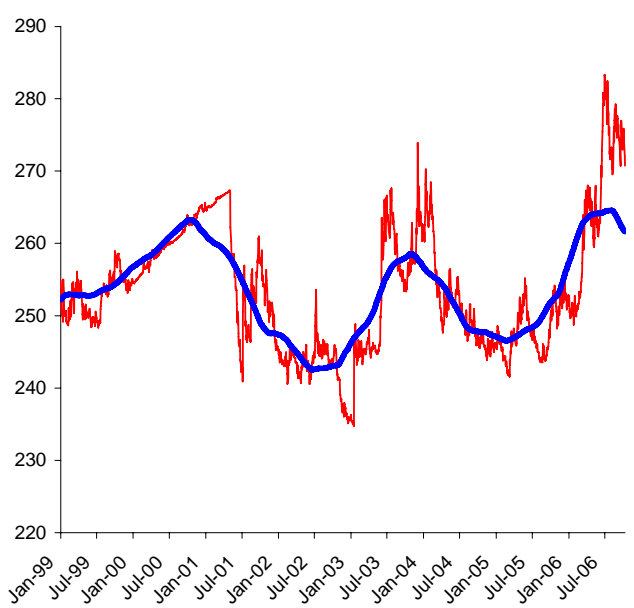

Slovakia

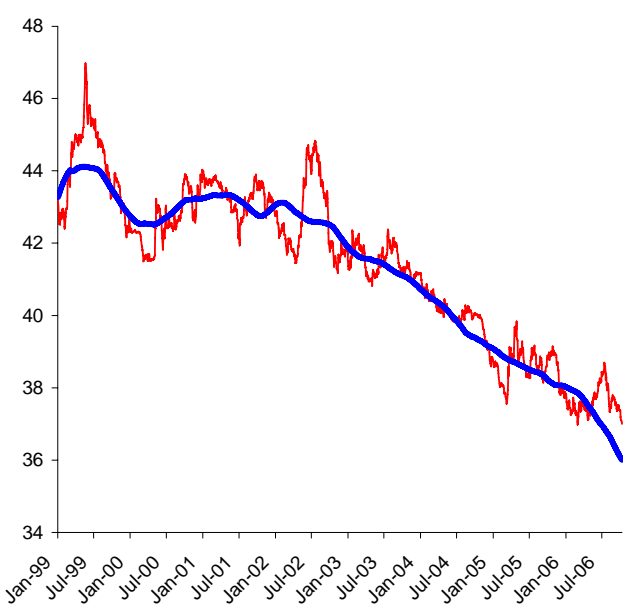

Romania

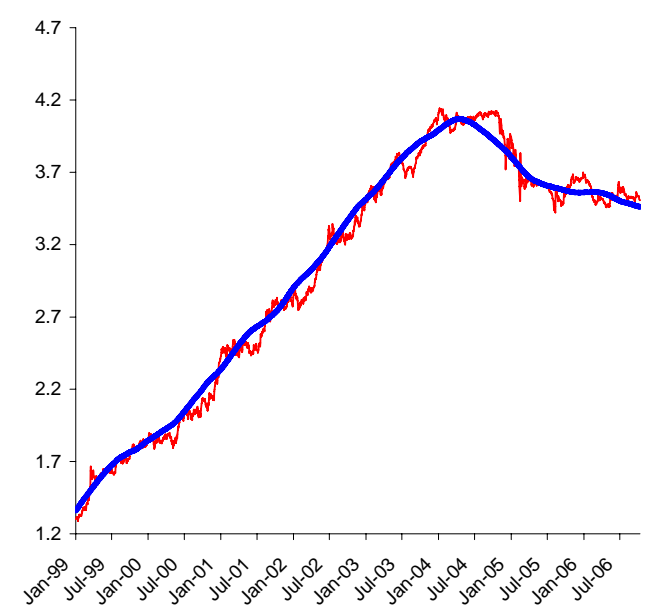


Table 1: Descriptive Statistics for Daily Exchange Rates, January 1999 to October 2006

\begin{tabular}{lrrrrr}
\hline & Czech Rep. & \multicolumn{1}{l}{ Hungary } & \multicolumn{1}{l}{ Poland } & \multicolumn{1}{l}{ Slovakia } & \multicolumn{1}{l}{ Romania } \\
\hline Mean & 32.525 & 253.596 & 4.083 & 41.404 & 3.028 \\
Median & 31.883 & 252.555 & 4.055 & 41.772 & 3.365 \\
Maximum & 38.583 & 283.350 & 4.935 & 46.977 & 4.143 \\
Minimum & 28.000 & 234.720 & 3.343 & 36.840 & 1.287 \\
Standard deviation & 2.730 & 8.808 & 0.314 & 2.226 & 0.840 \\
Coefficient of variation (\%) & 8.393 & 3.473 & 7.684 & 5.376 & 27.727 \\
Skewness & 0.276 & 0.585 & 0.301 & -0.268 & -0.476 \\
Kurtosis & 2.005 & 3.112 & 2.826 & 2.107 & 1.832 \\
Jarque-Bera test & 109.403 & 116.877 & 33.107 & 91.721 & 191.726 \\
& {$[0.000]$} & {$[0.000]$} & {$[0.000]$} & {$[0.000]$} & {$[0.000]$} \\
Observations & 2028 & 2028 & 2028 & 2028 & 2028 \\
\hline
\end{tabular}

Notes: $p$-values are reported in the brackets.

The selected new member states of the EU used highly heterogeneous de facto and de jure exchange rate policies. All countries in our sample allowed officially for free exchange rate movement to a significant degree. However, only Poland has been widely acknowledged not to intervene in the foreign exchange market (see Frömmel and Schobert, 2006). In turn, the Czech Republic and Slovakia allowed for considerable but controlled fluctuations of their currencies. Similarly, Hungary followed a policy of broad fluctuation bands (since 2001), while Romania had a de facto crawling peg until 2005.

These institutional differences cause also different developments of nominal exchange rates against the euro. Figure 1 presents the exchange rate developments for our sample countries. Generally, nominal exchange rate appreciation is visible for the Czech Republic and Slovakia. On the other hand, the Polish exchange rate does not seem to exhibit any pattern during the analyzed period. Finally, the Romanian leu depreciates substantially until 2004, which corresponds to the de facto crawling peg applied by the Bank of Romania. Furthermore, we can see in all selected NMS that the periods of high exchange rate volatility are usually associated with fast movements either in the appreciation or depreciation directions.

Table 1 provides the descriptive statistics between January 1999 and October 2006. Using the coefficient of variation (standard deviation divided by mean of individual 
currencies), Hungarian and Slovak currencies are characterized by the most stable exchange rates, followed by the Polish zloty and Czech koruna. However, there were different sources of volatility between the countries. Depreciation dominated only in Romania until 2004, while appreciation trends played an important role in the Czech Republic, Slovakia, and Romania (since 2005). The volatility in Hungary and Poland is mainly due to frequent changes of depreciation and appreciation developments.

\section{Results}

\subsection{GARCH Models}

The GARCH models are generally applied for the estimations of the conditional volatility of high-frequency (daily) exchange rate changes (see Baillie and Bollerslev, 1989). Following Engle and Gau (1997), we test one of the implications of the Krugman (1991) model of target zones. Krugman shows that the conditional volatility of exchange rate decreases as exchange rate approaches the edge of the target band. As a result, we estimate whether the deviation of the exchange rate from its target rate decreases the conditional volatility. Our baseline specification is a $\operatorname{GARCH}(1,1)$ model,

$$
\begin{gathered}
\Delta s_{j t}^{D}=\mu_{j}+\xi_{j t}, \\
\sigma_{j t}^{2}=\gamma_{j 1}+\gamma_{j 2} \xi_{j t-1}^{2}+\gamma_{j 3} \sigma_{j t-1}^{2}+\delta_{j}\left|s_{j t-1}^{D}-s_{j t-1}^{F}\right|+\omega_{j t},
\end{gathered}
$$

where $s^{D}$ and $s^{F}$ denote the spot daily exchange rate of currency to euro and the time varying target rate (moving average of \pm 120 trading days), respectively. We do not include any explanatory variables except for constant to equation (1), because daily exchange rates are expected to be influenced largely by news and other random events (see Bask and Fidrmuc, 2006, for the discussion of high-frequency exchange rate movements in the NMS). The constant term in equation (1), $\mu$, shows the average rate of appreciation or depreciation. The error term, $\xi$, of the mean equation (1) is assumed to have a time varying conditional variance, $\sigma^{2}$, specified by equation (2).

The conditional variance equation includes in addition to the $\mathrm{ARCH}$ term, $\xi_{t-1}^{2}$, the GARCH term, $\sigma_{t-1}^{2}$, and the distance between the spot and the target exchange rates, which is the major variable of our interest. Krugman's (1991) model implies that $\delta$ is negative, i.e. the conditional volatility decreases as exchange rate moves towards the edge of the band, as long as the announced or implicit target zones are fully credible. The opposite is true for the target zones subject to speculative attacks and low 
credibility. Finally, we expect no relationship between the conditional variance and the target exchange rates if no implicit target zones are specified.

Table 2 reports the estimations of (1) and (2) for the Czech Republic, Hungary, Poland, Slovakia, and Romania between January 1, 1999, and October 11, $2006 .{ }^{7}$ The results provide several interesting insights. First, the appreciation trend is confirmed for the Czech Republic, Poland and Slovakia. Our estimates at daily frequency imply an annual appreciation by 3 to 5 per cent. In turn, the Romanian leu and to a lesser degree the Hungarian forint depreciated significantly during the period. The former development corresponds to the de facto crawling peg applied by the Bank of Romania (see Crespo-Cuaresma et al., 2005b).

Second, we can see that the conditional volatility significantly depends on actual lagged squared error term and lagged conditional variance of the error term. Furthermore, the sum of the ARCH and GARCH term is relatively high, which indicates that the volatility of the shocks in all countries is quite persistent. Nevertheless, the sum of both coefficients is significantly lower than unity in all countries except for Romania.

Finally, we find that the deviation of the spot exchange rate from its target level is positive and highly significant for all the countries. This implies that as the target bands were implicit, they suffered generally under their low credibility. Similarly to e.g. Borghijs and Kuijs (2004) our results suggest that exchange rates do not act as shock absorbers. Our estimations show that exchange rate deviations from the medium-run average are characterized by significantly higher volatility. Thus, exchange rates may be a source of macroeconomic destabilization if they approach the ranges of the implicit target zones. The economic actors have to deal both with high deviations of exchange rates from their previous levels and their increased volatility. Nevertheless, we have to keep in mind that all coefficients are very small, although Hungary and Poland show the highest impact (in absolute value) of exchange rate deviations from the exchange rate target. In case of Slovakia, we have to include MA(1) in the mean equation to assure white noise in the residuals.

\footnotetext{
7 We report GARCH $(1,1)$ for the ease of exposition as we find that this specification has the lowest Schwartz information criterion for almost all countries.
} 
Table 2: Estimates of the Effect of the Spot Position to the Target Value on

\section{Conditional Volatility (GARCH Models), January 1999 to October 2006}

\begin{tabular}{lccccr}
\hline Country & Czech Rep. & \multicolumn{1}{l}{ Hungary } & \multicolumn{1}{l}{ Poland } & \multicolumn{1}{l}{ Slovakia } & \multicolumn{1}{c}{ Romania } \\
\hline$M$ & $-0.013^{*}$ & 0.005 & -0.020 & $-0.011^{* *}$ & $0.024^{* * *}$ \\
& $(-1.944)$ & $(1.019)$ & $(-1.558)$ & $(-1.681)$ & $(2.482)$ \\
$\gamma_{1}$ & $0.000^{* * *}$ & $0.000^{* * *}$ & $0.000^{* * *}$ & $0.000^{* * *}$ & 0.000 \\
& $(5.284)$ & $(-13.788)$ & $(3.307)$ & $(5.291)$ & $(0.291)$ \\
$\gamma_{2}$ & $0.075^{* * *}$ & $0.111^{* * *}$ & $0.081^{* * *}$ & $0.093^{* * *}$ & $0.114^{* * *}$ \\
& $(11.254)$ & $(20.482)$ & $(9.070)$ & $(10.527)$ & $(16.524)$ \\
$\gamma_{3}$ & $0.876^{* * *}$ & $0.881^{* * *}$ & $0.877^{* * *}$ & $0.852^{* * *}$ & $0.878^{* * *}$ \\
& $(67.241)$ & $(179.706)$ & $(78.776)$ & $(62.728)$ & $(147.083)$ \\
$\delta$ & $1.510^{* * *}$ & $3.670^{* * *}$ & $3.340^{* * *}$ & $1.430^{* * *}$ & $2.580^{* * *}$ \\
& $(3.472)$ & $(24.097)$ & $(6.124)$ & $(5.988)$ & $(7.472)$ \\
\hline$\gamma_{2}+\gamma_{3}=1$ & $0.951^{* * *}$ & $0.992^{* * *}$ & $0.958^{* * *}$ & $0.944^{* * *}$ & $0.992^{*}$ \\
& {$[0.000]$} & {$[0.005]$} & {$[0.000]$} & {$[0.000]$} & {$[0.052]$} \\
\hline SIC & -8.610 & -8.543 & -7.388 & -9.082 & -7.630 \\
$N$ & 2028 & 2028 & 2028 & 2028 & 2028 \\
\hline L-B(10), RES & 5.372 & 12.445 & 19.199 & 12.247 & 13.708 \\
& {$[0.865]$} & {$[0.256]$} & {$[0.038]$} & {$[0.200]$} & {$[0.187]$} \\
L-B(10), SQRES & 5.262 & 1.565 & 15.802 & 4.587 & 8.266 \\
& {$[0.873]$} & {$[0.999]$} & {$[0.105]$} & {$[0.869]$} & {$[0.603]$} \\
\hline
\end{tabular}

Notes: We report $z$-statistics in parenthesis and $p$-values of the Wald test that $\gamma_{2}+\gamma_{3}=1$ and the LjungBox $Q$-statistics of the $10^{\text {th }}$ lag for standard and squared residuals in brackets. $* * *, * *$, and $*$ denote significance at 1 per cent, 5 per cent, and 10 per cent, respectively. For clarity of the discussion in the text, the coefficients $\mu$ and $\delta$ are multiplied by 100 and $10^{4}$, respectively. 
Figure 2: Conditional Standard Deviation, January 1999 to October 2006

Czech Republic

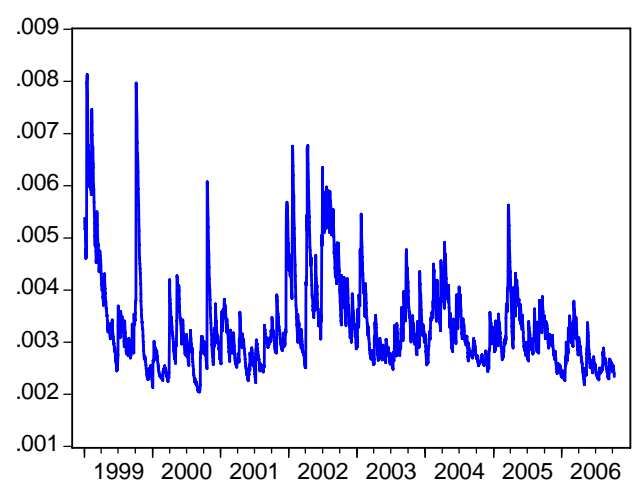

Poland

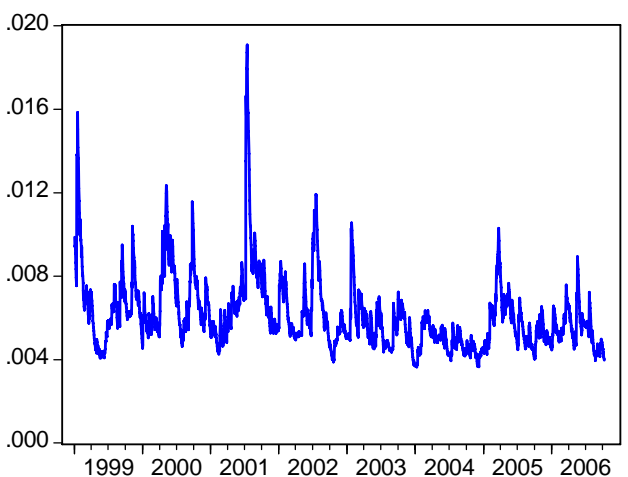

Hungary

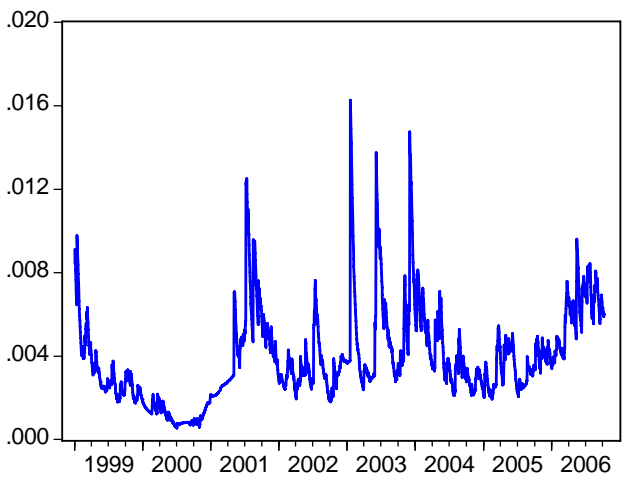

Slovakia

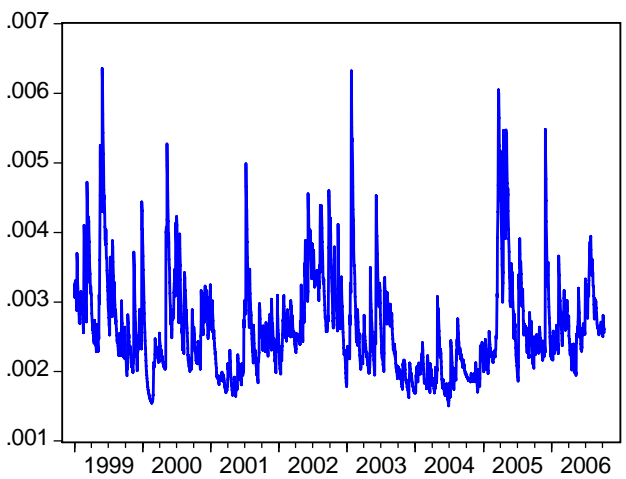

Romania

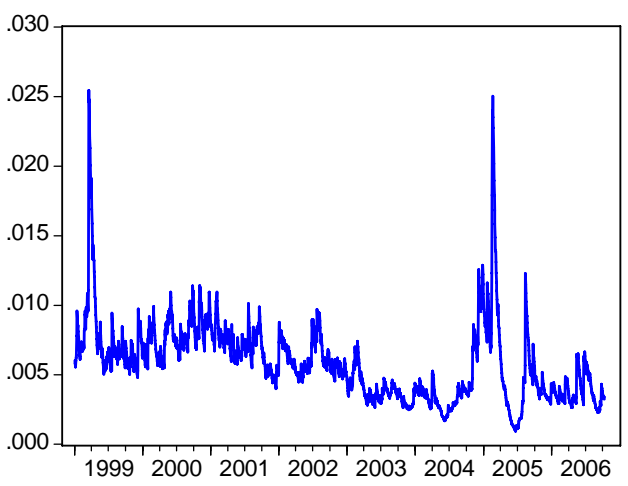


As a robustness check, we estimated the GARCH models with Hodrick-Prescott filter as an alternative to the moving average time varying target rate, $s^{F}$. The results are largely unchanged. ${ }^{8}$ Finally, we estimated the GARCH models also for the most recent sub-period after the countries (with the exception of Romania) joined the EU (that is, May 2004 to October 2006). We confirmed the positive coefficient for the distance of spot exchange rate from its implicit target value for all countries with the exception of the Czech Republic, while the coefficient for Poland is no longer significant (but positive) in this sub-sample (see Appendix).

Figure 2 presents the conditional variance for all countries in our sample. The Czech Republic and Slovakia show a lower conditional variance than other countries of the region in selected periods. Nevertheless, we can see frequent changes of the conditional variance in all NMS.

\subsection{TARCH Models}

We can often see that the volatility of financial variables is different along positive and negative trends (see Engle and $\mathrm{Ng}, 1993$ ). The downwards movements of share prices are usually associated with higher volatility of financial data. In this regard, Zakoïan (1990) and Glosten et al. (1993) proposed the threshold ARCH models to analyze asymmetric volatility.

Economic policy may be also likely to fight against the currency depreciation more intensively than against the appreciation. One reason for this asymmetry can be the fact that countries in this region typically experience real exchange rate appreciation partially due to the Balassa-Samuelson effect (Égert and Lommatzsch, 2004, García Solanes et al., 2008, and MacDonald and Wojcik, 2008). Additionally, the ERM II has even some inherited certain asymmetric components as countries are allowed to appreciate the central parity, but its depreciation causes a violation of the exchange rate criterion (see de Grauwe and Schnabel, 2005). ${ }^{9}$ This pattern of behavior may play an

\footnotetext{
${ }^{8}$ We have also included the distance between the spot and implicit target rate in the mean equation. Except Romania, the coefficient was never significant at any obvious significance level. In case of Romania, we find that the positive impact of distance on the changes of exchange rate, which likely corresponds to the exchange rate policy of crawling band. These results are available upon request.

${ }^{9}$ In March 2007, Slovakia appreciated the central parity by more than 8 per cent.
} 
important role already during the preparation for the membership in the ERM II. Thus, the exchange rate target zones may be more credible if exchange rate is approaching the depreciation limit (that is, the upper bound according to our definition of exchange rates) of the implicit target band.

In turn, national economic policies may define their objectives in relation to the national competitiveness. Several transition countries have been often concerned by the excessive exchange rate appreciation and some even aimed to stabilize its real exchange rate (see Coricelli et al., 2006). This may be especially important for the NMS with the strong appreciation trends due to the Balassa-Samuelson effect, deregulation of prices and tradable prices appreciation. Finally, market participants may behave differently if exchange rate is overvalued or undervalued. Actually, Crespo-Cuaresma et al. (2005a) find important asymmetric volatility effects both in EU15 countries as well as in the NMS.

Correspondingly, we extend the standard TARCH model as we take into account also the position of the spot exchange rate in relation to its target value. Our estimation specification is as follows,

$$
\begin{gathered}
\Delta s_{j t}^{D}=\mu_{j}+\xi_{j t}, \\
\sigma_{j t}^{2}=\gamma_{j 1}+\gamma_{j 2} \xi_{j t-1}^{2}+\gamma_{j 3} \sigma_{j t-1}^{2}+\gamma_{j 4} D_{j t-1}^{a r c h} \xi_{j t-1}^{2}+\delta_{j 1}\left|s_{j t-1}^{D}-s_{j t-1}^{F}\right|+\delta_{j 2} D_{j t-1}^{s}\left|s_{j t-1}^{D}-s_{j t-1}^{F}\right|+\omega_{j t},
\end{gathered}
$$

where $D^{\text {arch }}$ is a dummy variable which equals 1 if the residual from the mean equation, $\xi_{t}$, is negative and zero otherwise. Similarly, $D^{s}$ is a dummy variable equal to 1 if the spot exchange rate is lower than the target value, that is, if the exchange rate is in the appreciation part of the target zone.

The asymmetric ARCH terms, $\gamma_{4}$, is insignificant only in the Czech Republic and Slovakia, while the coefficient is negative in Poland and Hungary, and positive in Romania. As a result, negative (squared) residuals from the mean equation lower significantly to the exchange rate volatility in Hungary and Poland. Because the residuals are computed only from the mean equation, this does not take into account whether the spot exchange rate is also below the target value (that is, in the appreciation part). For these two countries, the appreciation movements are less volatile also if they start in the depreciation part of the implicit target band. The opposite is true for Romania. 
Table 3: Asymmetric Estimates of the Effect of Spot Position to Target Value on Conditional Volatility (TARCH Models), January 1999 to October 2006

\begin{tabular}{|c|c|c|c|c|c|}
\hline Country & Czech Rep. & Hungary & Poland & Slovakia & Romania \\
\hline \multirow[t]{2}{*}{$\mu$} & $-0.019^{* * *}$ & 0.004 & -0.016 & $-0.012^{*}$ & $0.018^{*}$ \\
\hline & $(-2.641)$ & $(0.835)$ & $(-1.318)$ & $(-1.903)$ & $(1.897)$ \\
\hline \multirow[t]{2}{*}{$\gamma_{1}$} & $0.000^{* * *}$ & $0.000^{* * *}$ & $0.000^{* * *}$ & $0.000^{* * *}$ & 0.000 \\
\hline & $(4.843)$ & $(-11.292)$ & $(4.667)$ & $(4.766)$ & $(0.104)$ \\
\hline \multirow[t]{2}{*}{$\gamma_{2}$} & $0.054^{* * *}$ & $0.140^{* * *}$ & $0.100^{* * *}$ & $0.089^{* * *}$ & $0.088^{* * *}$ \\
\hline & $(4.756)$ & (17.100) & $(8.402)$ & (8.229) & (13.207) \\
\hline \multirow[t]{2}{*}{$\gamma_{3}$} & $0.879^{* * *}$ & $0.893^{* * *}$ & $0.893^{* * *}$ & $0.866^{* * *}$ & $0.879^{* * *}$ \\
\hline & $(58.196)$ & $(172.148)$ & $(81.045)$ & $(63.517)$ & $(129.651)$ \\
\hline \multirow[t]{2}{*}{$\gamma_{4}$} & 0.017 & $-0.086^{* * *}$ & $-0.085^{* * *}$ & -0.018 & $0.054^{* * *}$ \\
\hline & $(1.265)$ & $(-6.816)$ & $(-5.192)$ & $(-1.284)$ & $(3.785)$ \\
\hline \multirow[t]{2}{*}{$\delta_{1}$} & $1.200^{* * *}$ & $1.760^{* * *}$ & 1.100 & $0.866^{* * *}$ & $1.730^{* * *}$ \\
\hline & $(3.186)$ & (19.882) & $(1.512)$ & $(3.898)$ & $(5.208)$ \\
\hline \multirow[t]{2}{*}{$\delta_{2}$} & $3.840^{* * *}$ & $2.330^{* * *}$ & $2.820^{* * *}$ & $1.660^{* * *}$ & $1.910^{* * *}$ \\
\hline & $(5.276)$ & $(18.062)$ & (4.307) & $(6.090)$ & $(4.101)$ \\
\hline \multirow[t]{2}{*}{$\gamma_{2}+\gamma_{3}=1$} & $0.932^{* * *}$ & $1.034^{* * *}$ & $0.992^{* * *}$ & $0.955^{* * *}$ & $0.967^{* * *}$ \\
\hline & {$[0.000]$} & {$[0.000]$} & {$[0.000]$} & {$[0.000]$} & {$[0.000]$} \\
\hline \multirow[t]{2}{*}{$\gamma_{2}+\gamma_{3}+\gamma_{4}=1$} & $0.950^{* * *}$ & $0.948^{* * *}$ & $0.907^{* * *}$ & $0.937^{* * *}$ & $1.021^{*}$ \\
\hline & {$[0.000]$} & {$[0.000]$} & {$[0.000]$} & {$[0.000]$} & {$[0.053]$} \\
\hline$S I C$ & -8.611 & -8.560 & -7.392 & -9.083 & -7.629 \\
\hline$N$ & 2028 & 2028 & 2028 & 2028 & 2028 \\
\hline \multirow[t]{2}{*}{ L-B(10), RES } & 5.709 & 11.321 & 15.462 & 11.773 & 11.948 \\
\hline & {$[0.839]$} & [0.333] & {$[0.051]$} & {$[0.226]$} & [0.289] \\
\hline \multirow[t]{2}{*}{ L-B(10), SQRES } & 4.440 & 1.577 & 13.125 & 4.264 & 6.945 \\
\hline & [0.925] & [0.999] & [0.108] & [0.893] & [0.731] \\
\hline
\end{tabular}

Notes: We report $z$-stats in parenthesis and p-values of the Wald test that $\gamma_{2}+\gamma_{3}=1$ and $\gamma_{2}+\gamma_{3}+\gamma_{4}=1$, as well as the Ljung-Box $Q$-statistics of the $10^{\text {th }}$ lag for standard and squared residuals in brackets. ***, **, and * denote significance at 1 per cent, 5 per cent, and 10 per cent, respectively. For clarity of the discussion in the text, coefficients $\mu$ and $\delta$ are multiplied by 100 and $10^{4}$, respectively. 
Figure 3: Conditional Standard Deviation and the Deviation of Spot Exchange Rate from the Target Rate, January 1999 to October 2006
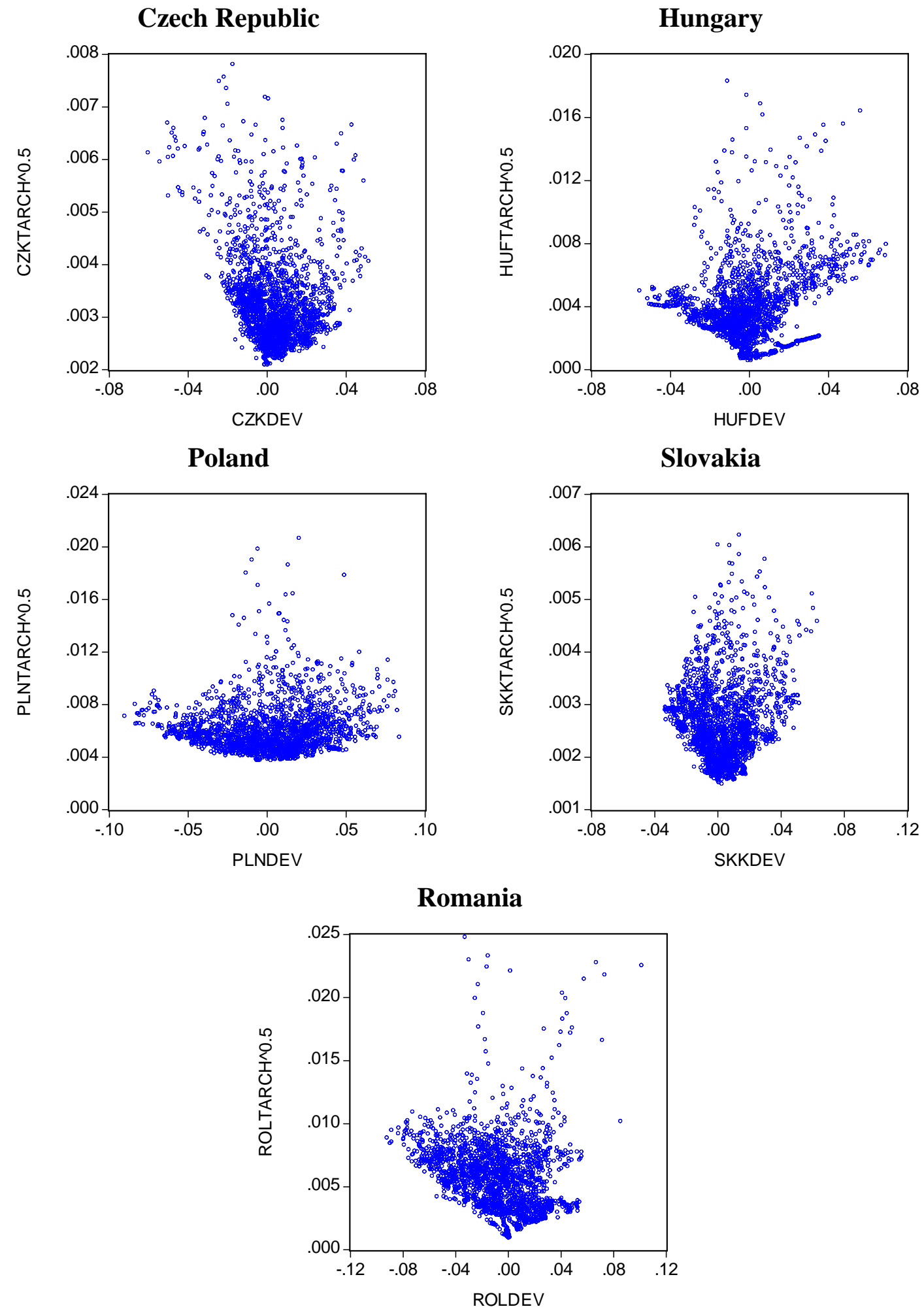
Furthermore, we can see that that the asymmetric effects of exchange rate misalignments, $\delta_{2}$, are significant in all countries (see Table 3 ). ${ }^{10}$ Negative deviations of the spot exchange rate from the target value (that is, spot exchange rate located in the appreciation area) increase significantly the volatility of daily exchange rates. This finding indicates that the target zones are less credible in the appreciation part in these countries. ${ }^{11}$ By contrast, we can see that the persistence of exchange rate shocks is lower during the appreciation periods. Only in Romania we can find as before that the exchange rate volatility is persistent in the appreciation area of the implicit target zone.

Additionally, we performed several sensitivity analyses similar to those for GARCH models. First, the time varying implicit target rate was proxied by Hodrick-Prescott filter instead of moving average. Next, EGARCH model was applied to assess the asymmetries further. Overall, the results from sensitivity analysis confirm those of baseline specification.

Figure 3 documents the asymmetrical relationship between the exchange rate volatility and the relative level of exchange rates as compared to the targets based on the results reported in Table 3. On the one hand, we can see that the conditional variance increases as the actual exchange rate deviates from its implicit target rate. This relationship seems to be asymmetric in all NMS except for Poland. In particular, the relationship between the exchange rate deviations from the target value is steeper in the appreciation area.

On the other hand, the points with the extreme conditional volatility are often observed around the target values of exchange rates, which is consistent with the target zone model. However, there are also observations with comparably high values of exchange rate volatility in the depreciation area of the implicit target zones especially in Hungary, Slovakia and Romania.

\footnotetext{
${ }^{10}$ Correspondingly, the development pattern of exchange rate volatility is similar to that presented in Figure 2. Detailed results are available upon request from authors.

${ }^{11}$ Note that, by definition, the opposite is true for the depreciation side of the target zone.
} 


\section{Conclusions}

We analyze high frequency exchange rate dynamics in selected NMS that introduced inflation targeting regime. Our sample consists of five NMS (Czech Republic, Hungary, Poland, Slovakia and Romania). These countries maintained relatively free exchange rates between 1999 and 2006 .

Following the target zone model by Krugman (1991), we examine the exchange rate volatility in connection to the estimated target exchange rate. We estimate GARCH models of daily exchange rate volatility. We find that the volatility is quite persistent in all NMS. In addition, the exchange rate is more volatile if it is far away from its implicit target rate in all analyzed countries. This indicates that there may be implicit exchange rate target zones in some of these countries, however, which suffer under insufficient credibility. Finally, our TARCH results point to systematic asymmetries in the exchange rate volatility in the NMS. The volatility of exchange rate is significantly more pronounced especially during the periods of exchange rate appreciation in all analyzed countries.

Given the persistent volatility of exchange rates in all analyzed NMS, the policy of inflation targeting seems to be an attractive option before the euro adoption. Our sensitivity analysis for the recent period (2004 to 2006) showed that Poland and the Czech Republic, that is the countries with the longest experience with inflation targeting, have experienced also less volatility of exchange rate with respect to its medium-term target level.

\section{References}

Baillie, R.T., Bollerslev, T., 1989, The message in daily exchange rates: A conditional-variance tale. Journal of Business and Economic Statistics 7, 297-305.

Bask, M., Fidrmuc, J., 2006, Fundamentals and technical trading: Behavior of exchange rates in the CEECs. Discussion Paper No. 10/2006. Bank of Finland, Helsinki.

Bessec, M., 2003, The asymmetric exchange rate dynamics in the EMS: A time varying threshold test, European Review of Economics and Finance 2, 3-40.

Borghijs, A., Kuijs, L., 2004, Exchange rates in Central Europe: A blessing of a curse? Working Paper No. WP/04/2. International Monetary Fund, Washington.

Calvo, G., Reinhart, C. 2002, Fear of floating, Quarterly Journal of Economics 117, 379-408.

Chmelarova, V., Schnabl, G., 2006, Exchange rate stabilization in developed and underdeveloped capital markets. Working Paper No. 636. European Central Bank, Frankfurt. 
Chung, C. S., Tauchen, G., 2001, Testing target-zone models using efficient method of moments, Journal of Business Economics and Statistics 19, 255-269.

Coricelli, F. Jazbec, B., Masten, I., 2006, Exchange Rate Pass-through in EMU Acceding Countries: Empirical Analysis and Policy Implications, Journal of Banking and Finance, 30, 1375-1391.

Crespo-Cuaresma, J., Égert, B., MacDonald, R., 2005a, Non-linear exchange rate dynamics in target zones: A bumpy road towards a honeymoon. Working Paper No. 771, Williams Davidson Institute, Michigan.

Crespo-Cuaresma, J., Fidrmuc, J., Silgoner, M. A. 2005b, On the road: The path of Bulgaria, Croatia and Romania to the EU and the euro. Europe-Asia Studies 57, 843-858.

De Grauwe, P. Schnabl, G., 2005, Nominal versus real convergence - EMU entry scenarios for the new member states. Kyklos 58, 537-555.

Edison, H. J., Miller, M. H., Williamson, J., 1987, On evaluating and extending the target zone proposal, Journal of Policy Modeling 9, 199-227.

Égert, B., Lommatzsch, K., 2004, Equilibrium exchange rates in transition: The tradable price-based real appreciation and estimation uncertainty. Working Paper No. 676, William Davidson Institute, Michigan.

Égert, B., 2007, Central bank interventions, communication and interest rate policy, Journal of Comparative Economics 35, 387-413.

Égert, B., Komárek, L. 2006, Foreign exchange interventions and interest rate policy in the Czech Republic: Hand in glove?, Economic Systems 30, 121-140.

Eichengreen, B., 1994, International monetary arrangements for the 21st century (The Brookings Institution, Washington, DC).

Engle, R.F., Gau, Y., 1997, Conditional volatility of exchange rates under a target zone. Working Paper No. 06/97, University of California, San Diego.

Engle, R.F., Ng, V.K., 1993, Measuring and testing the impact of news on volatility. Journal of Finance 48, 1022-1082.

Fidrmuc, J., Korhonen, I. 2006, Meta-analysis of the business cycle correlation between the euro area and the CEECs, Journal of Comparative Economics 34, 518-537.

Frömmel, M., Schobert, F. 2006, Exchange rate regimes in Central and East European countries: Deeds vs. words. Journal of Comparative Economics 34, 467-483.

García Solanes, J., Portero, F. I. S., Torrejón, F.F., 2008, Beyond the Balassa-Samuelson effect in some new member states of the European Union. Economic Systems 32, forthcoming.

Geršl, A., Holub, T., 2006, Foreign exchange interventions under inflation targeting: The Czech Experience, Contemporary Economic Policy 24, 475-491.

Ghosh, A. R., Gulde, A.M., Wolf, H. C., 2003, Exchange rate regimes: Choices and consequences (The MIT Press, Cambridge).

Glosten, L. R., Jaganathan, R., Runkle, D., 1993, On the relation between the expected value and the volatility of the normal excess return on stocks. Journal of Finance 48, 1779-1801. 
Horváth, R., 2007, Ready for euro? Evidence on EU new member states, Applied Economics Letters, forthcoming.

Ito, T., Yabu, T., 2007, What promotes Japan to intervene in the forex market? A new approach to a reaction function, Journal of International Money and Finance 26, 193-212.

Kempa, B., Nelles, M., 1999, The theory of exchange rate target zones, Journal of Economic Surveys 13, 173-210.

Krugman, P., 1991, Target zone and exchange rate dynamics, Quarterly Journal of Economics 56, 669682.

Kočenda, E., Valachy, J., 2006, Exchange rate volatility before and after regime shift: A new measure and new evidence from transition, Journal of Comparative Economics 34, 727-753.

MacDonald, R., Wojcik, C., 2008, Catching-up and inflation differentials in a heterogeneous monetary union: Some implications for the euro area and new EU member states, Economic Systems 32, forthcoming.

Markiewicz, A., 2006, Choice of exchange rate regime in transition economies: An empirical analysis, Journal of Comparative Economics 34, 484-498.

Nell, M., 2004, Monetary policy in the Slovak Republic: Implicit inflation targeting and the choice of an optimal exchange rate regime, National Bank of Slovakia, BIATEC 11, 22-25.

NBS, 2004, Monetary programme (National Bank of Slovakia, Bratislava).

Obstfeld, M., Rogoff, K., 1998, Foundations of international macroeconomics (The MIT Press, Cambridge).

Sarno, L., Taylor, M. P., 2002, The economics of exchange rates. (Cambridge University Press, Cambridge).

Schnabl, G., 2008, Exchange rate volatility and growth in small open economies at the EMU periphery, Economic Systems 32, forthcoming.

Williamson, J., 1985, The exchange rate system (Institute for International Economics, Washington D.C.).

Zakoïan, J.M., 1994, Threshold heteroskedastic models, Journal of Economic Dynamics and Control 18, 931-944. 


\section{Appendix: Sensitivity Analysis}

In addition to the comparison of GARCH and TARCH models, this appendix presents additional sensitivity analysis according the following lines. First, we use the HodrickPrescott filter in Table A.1 to proxy the target value of the exchange rate instead of the moving average. The smoothing parameter of the Hodrick Prescott filter was selected as $\lambda=6,812,100$, which corresponds to approximately $s=261$ trading days (the average number of trading days in our data sample) and the generalized relationship $\lambda=100 s^{2}$ (see Artis et al., 2003, Appendix E, page 53). We estimate the GARCH and TARCH models for the same period in order to make the results directly comparable.

Second, we present our estimations for the period after nearly all analyzed countries (except Romania) joined the EU (that is, May 2004 to October 2006). The EU membership can present a structural break in several time series e.g. due to improved access to the EU market in the area of sensitive products and increased export revenues. Foreign direct investment increased also during the accession to the EU. Romania, for example, experienced a reversal of the depreciation trend to exchange rate appreciation in 2004 (see Figure 1). Although Romania did not join the EU in May 2004, the negotiations on the accession of Romania (and Bulgaria) progressed significantly around this date.

Furthermore, the recent period excludes the first years of inflation targeting policy in the Czech Republic and Poland (inflation targeting was officially introduced in 1998 in both countries), which might be less credible in the first year of application. We expect that countries following pure inflation targeting policy are likely to show no significant differences in exchange rate volatility with respect to the target exchange rates. Alternatively, we used also different sub-samples (e.g. the ERM II membership of Slovakia), which are available upon request.

Both extensions confirm the previous results. Mostly important from the perspective of the analyzed topic, the deviation between the spot exchange rate and the various proxies of the target level is found to be positive and significant for all countries except Poland and the Czech Republic in the period of the EU membership. In the former case, the coefficient is positive while insignificant, while it is negative and insignificant at the latter case. Actually, this finding confirms our previous conclusions, because both 
Poland and the Czech Republic have followed efficiently the policy of inflation targeting in this period. Thus, we can see that the application of the inflation targeting helps possibly to reduce the volatility of the exchange rates.

We performed both extensions also for TARCH models with similar results (see Table A.3 and A.4). Furthermore, we estimated asymmetric effects also in exponential generalized autoregressive conditional heteroskedasticity (EGARCH) models proposed by Nelson (1991), which are defined as

$$
\begin{gathered}
\Delta s_{j t}^{D}=\mu_{j}+\xi_{j t}, \\
\log \left(\sigma_{j t}^{2}\right)=\gamma_{j 1}+\gamma_{j 2}\left|\frac{\xi_{j t-1}}{\sigma_{j t-1}}\right|+\gamma_{j 3} \frac{\xi_{j t-1}}{\sigma_{j t-1}}+\gamma_{j 4} \log \left(\sigma_{j t-1}^{2}\right)+\delta_{j 1}\left|s_{j t-1}^{D}-s_{j t-1}^{F}\right|+\delta_{j 2} D_{j t-1}^{s}\left|s_{j t-1}^{D}-s_{j t-1}^{F}\right|+\omega_{j t}
\end{gathered}
$$

Similarly to TARCH models, $D^{s}$ denotes a dummy variable equal to 1 if the spot exchange rate is lower than the target value. Thus, we can again see whether the deviation between the spot and target exchange rates has asymmetric effects on exchange rate volatility in addition to asymmetric leverage effects, which are shown by a significant coefficient $\gamma_{3}$.

Table A.5 presents the results of our EGARCH estimations. Stationarity constraint is met if $\gamma_{4}<1$. Although this coefficient is again relatively high, the stationarity criterion is fulfilled in all countries. We can see that the asymmetric leverage effects are confirmed for all countries except the Czech Republic. Finally, the exchange rate position with respect to its target value has asymmetric effects in the Czech Republic, Hungary, and Slovakia. Thus, this result confirms the pattern found by the TARCH models.

\section{References}

Artis, M. J., Marcellino, M., Proietti, T. 2003. Dating the euro area business cycles, Discussion Paper No. 3696. CEPR, London.

Nelson, Daniel B. 1991. Conditional heteroskedasticity in asset returns: A new approach, Econometrica $59,347-370$. 
Table A.1: Estimates of the Effect of the Spot Position to the Target Value on Conditional Volatility (GARCH Models), Target Value Proxied by the HP Filter, January 1999 to October 2006

\begin{tabular}{lcccrr}
\hline Country & Czech Rep. & \multicolumn{1}{c}{ Hungary } & \multicolumn{1}{c}{ Poland } & \multicolumn{1}{l}{ Slovakia } & \multicolumn{1}{c}{ Romania } \\
\hline$\mu$ & $-0.014^{* * *}$ & 0.005 & -0.021 & -0.009 & $0.028^{* * *}$ \\
& $(-2.049)$ & $(1.091)$ & $(-1.647)$ & $(-1.258)$ & $(3.050)$ \\
$\gamma_{1}$ & $0.000^{* * *}$ & $0.000^{* * *}$ & $0.000^{* * *}$ & $0.000^{* * *}$ & 0.000 \\
& $(4.350)$ & $(-16.940)$ & $(3.231)$ & $(4.195)$ & $(-1.269)$ \\
$\gamma_{2}$ & $0.064^{* * *}$ & $0.078^{* * *}$ & $0.074^{* * *}$ & $0.094^{* * *}$ & $0.119^{* * *}$ \\
& $(9.558)$ & $(17.342)$ & $(8.236)$ & $(8.617)$ & $(16.771)$ \\
$\gamma_{3}$ & $0.882^{* * *}$ & $0.893^{* * *}$ & $0.875^{* * *}$ & $0.811^{* * *}$ & $0.874^{* * *}$ \\
& $(70.056)$ & $(160.064)$ & $(70.109)$ & $(39.875)$ & $(142.240)$ \\
$\delta$ & $3.390^{* * *}$ & $5.870^{* * *}$ & $6.640^{* * *}$ & $4.840^{* * *}$ & $4.420^{* * *}$ \\
& $(5.346)$ & $(20.585)$ & $(7.006)$ & $(6.935)$ & $(8.022)$ \\
\hline$\gamma_{2}+\gamma_{3}=1$ & $0.946^{*}$ & $0.971^{* * *}$ & $0.948^{* * *}$ & $0.905^{* * *}$ & 0.993 \\
& {$[0.052]$} & {$[0.000]$} & {$[0.000]$} & {$[0.000]$} & {$[0.113]$} \\
\hline SIC & -8.615 & -8.588 & -7.399 & -9.096 & -7.632 \\
$N$ & 2028 & 2028 & 2028 & 2028 & 2028 \\
\hline L-B(10), RES & 5.630 & 11.463 & 21.411 & 11.170 & 13.625 \\
& {$[0.845]$} & {$[0.323]$} & {$[0.018]$} & {$[0.264]$} & {$[0.191]$} \\
L-B(10), SQRES & 6 & 2.519 & 15.832 & 2.843 & 6.688 \\
& {$[0.815]$} & {$[0.991]$} & {$[0.105]$} & {$[0.970]$} & {$[0.754]$} \\
\hline
\end{tabular}

Notes: We report $z$-statistics in parenthesis and $p$-values of the Wald test that $\gamma_{2}+\gamma_{3}=1$ and the LjungBox $Q$-statistics of the $10^{\text {th }}$ lag for standard and squared residuals in brackets. ${ }^{* *},{ }^{* *}$, and $*$ denote significance at 1 per cent, 5 per cent, and 10 per cent, respectively. For clarity of the discussion in the text, coefficients $\mu$ and $\delta$ are multiplied by 100 and $10^{4}$, respectively. 
Table A.2: Estimates of the Effect of the Spot Position to the Target Value on Conditional Volatility (GARCH Models), EU Membership Sub-Sample, May 2004 to October 2006

\begin{tabular}{|c|c|c|c|c|c|}
\hline Country & Czech Rep. & Hungary & Poland & Slovakia & Romania \\
\hline \multirow[t]{2}{*}{$M$} & $-0.022^{* *}$ & -0.003 & $-0.049^{* *}$ & $-0.018^{*}$ & -0.007 \\
\hline & $(-2.124)$ & $(-0.222)$ & $(-2.380)$ & $(-1.654)$ & $(-0.565)$ \\
\hline \multirow[t]{2}{*}{$\gamma_{1}$} & $0.000^{*}$ & 0.000 & 0.000 & $0.000^{* *}$ & 0.000 \\
\hline & (1.694) & $(0.990)$ & $(1.552)$ & $(2.530)$ & $(0.276)$ \\
\hline \multirow[t]{2}{*}{$\gamma_{2}$} & $0.064^{* * *}$ & $0.080^{* * *}$ & $0.064^{* * *}$ & $0.073^{* * *}$ & $0.158^{* * *}$ \\
\hline & $(4.400)$ & (4.486) & (3.292) & $(5.024)$ & (11.539) \\
\hline \multirow[t]{2}{*}{$\gamma_{3}$} & $0.911^{* * *}$ & $0.900^{* * *}$ & $0.873^{* * *}$ & $0.900^{* * *}$ & $0.837^{* * *}$ \\
\hline & $(45.785)$ & $(47.926)$ & (18.574) & $(52.369)$ & $(100.242)$ \\
\hline \multirow[t]{2}{*}{$\delta$} & -0.033 & $1.900^{* * *}$ & 2.920 & $0.526^{* *}$ & $3.510^{* * *}$ \\
\hline & $(-0.053)$ & (2.993) & $(1.424)$ & $(2.528)$ & (7.453) \\
\hline \multirow[t]{2}{*}{$\gamma_{2}+\gamma_{3}=1$} & $0.975^{*}$ & $0.980^{* *}$ & $0.937^{*}$ & $0.973^{* * *}$ & 0.994 \\
\hline & [0.067] & [0.023] & {$[0.076]$} & {$[0.000]$} & [0.535] \\
\hline$S I C$ & -8.910 & -8.210 & -7.663 & -9.123 & -8.183 \\
\hline$N$ & 638 & 638 & 638 & 638 & 638 \\
\hline \multirow[t]{2}{*}{ L-B(10), RES } & $18.202^{*}$ & $16.774^{*}$ & 13.424 & 10.748 & 4.428 \\
\hline & {$[0.052]$} & {$[0.080]$} & {$[0.201]$} & {$[0.293]$} & [0.926] \\
\hline \multirow[t]{2}{*}{ L-B(10), SQRES } & $16.696^{*}$ & 13.526 & 8.466 & 2.436 & 4.867 \\
\hline & [0.081] & [0.196] & {$[0.583]$} & [0.983] & [0.900] \\
\hline
\end{tabular}

Notes: We report $z$-statistics in parenthesis and $p$-values of the Ljung-Box $Q$-statistics of the $10^{\text {th }}$ lag for standard and squared residuals in brackets. ${ }^{* * *},{ }^{* *}$, and $*$ denote significance at 1 per cent, 5 per cent, and 10 per cent, respectively. For clarity of the discussion in the text, the coefficients $\mu$ are multiplied by 100. 
Table A.3: Estimates of the Effect of the Spot Position to the Target Value on Conditional Volatility (TARCH Models), Target Value Proxied by the HP Filter,

January 1999 to October 2006

\begin{tabular}{|c|c|c|c|c|c|}
\hline Country & Czech Rep. & Hungary & Poland & Slovakia & Romania \\
\hline \multirow[t]{2}{*}{$\mu$} & $-0.018^{* *}$ & 0.008 & -0.018 & $-0.016^{* * *}$ & $0.022^{* *}$ \\
\hline & $(-2.535)$ & (1.606) & $(-1.465)$ & $(-2.594)$ & $(2.344)$ \\
\hline \multirow[t]{2}{*}{$\gamma_{1}$} & $0.000^{* * *}$ & $0.000^{* * *}$ & $0.000^{* * *}$ & 0.000 & 0.000 \\
\hline & (3.987) & $(-15.935)$ & $(4.531)$ & $(-0.659)$ & $(-1.299)$ \\
\hline \multirow[t]{2}{*}{$\gamma_{2}$} & $0.042^{* * *}$ & $0.098^{* * *}$ & $0.091^{* * *}$ & $0.008^{* * *}$ & $0.092^{* * *}$ \\
\hline & $(4.285)$ & (16.048) & (7.587) & $(3.744)$ & $(14.275)$ \\
\hline \multirow[t]{2}{*}{$\gamma_{3}$} & $0.026^{* *}$ & $-0.073^{* * *}$ & $-0.088^{* * *}$ & $-0.009^{* * *}$ & $0.066^{* * *}$ \\
\hline & $(2.239)$ & $(-8.437)$ & $(-5.373)$ & $(-2.776)$ & $(4.180)$ \\
\hline \multirow[t]{2}{*}{$\gamma_{4}$} & $0.898^{* * *}$ & $0.911^{* * *}$ & $0.894^{* * *}$ & $0.978^{* * *}$ & $0.873^{* * *}$ \\
\hline & (73.773) & (166.920) & (74.290) & (403.006) & $(128.756)$ \\
\hline \multirow[t]{2}{*}{$\delta_{1}$} & $2.280^{* * *}$ & $3.300^{* * *}$ & $3.430^{* * *}$ & $0.827^{* * *}$ & $3.410^{* * *}$ \\
\hline & $(3.674)$ & $(15.814)$ & $(2.814)$ & $(7.413)$ & $(5.473)$ \\
\hline \multirow[t]{2}{*}{$\delta_{2}$} & $1.830^{* * *}$ & $2.730^{* * *}$ & $4.200^{* * *}$ & $0.955^{* * *}$ & $2.060^{* * *}$ \\
\hline & (3.088) & $(12.518)$ & (3.983) & $(9.792)$ & $(2.784)$ \\
\hline \multirow[t]{2}{*}{$\gamma_{2}+\gamma_{3}=1$} & $0.939^{* * *}$ & $1.009^{*}$ & $0.985^{* * *}$ & $0.987^{* * *}$ & $0.965^{* * *}$ \\
\hline & {$[0.000]$} & {$[0.054]$} & {$[0.000]$} & {$[0.000]$} & {$[0.000]$} \\
\hline \multirow[t]{2}{*}{$\gamma_{2}+\gamma_{3}+\gamma_{4}=1$} & $0.965^{* * *}$ & $0.936^{* * *}$ & $0.897^{* * *}$ & $0.978^{* * *}$ & $1.031^{* *}$ \\
\hline & {$[0.001]$} & {$[0.001]$} & {$[0.000]$} & {$[0.000]$} & {$[0.012]$} \\
\hline$S I C$ & -8.610 & -8.606 & -7.404 & -9.094 & -7.630 \\
\hline$N$ & 2028 & 2028 & 2028 & 2028 & 2028 \\
\hline \multirow[t]{2}{*}{ L-B(10), RES } & 5.957 & 9.609 & $16.640^{* *}$ & 9.966 & 12.414 \\
\hline & {$[0.819]$} & {$[0.475]$} & {$[0.034]$} & {$[0.353]$} & {$[0.258]$} \\
\hline \multirow[t]{2}{*}{ L-B(10), SQRES } & 5.288 & 2.668 & 12.786 & 14.060 & 5.852 \\
\hline & {$[0.871]$} & {$[0.988]$} & {$[0.119]$} & {$[0.120]$} & {$[0.828]$} \\
\hline
\end{tabular}

Notes: We report $z$-stats in parenthesis and p-values of the Wald test that $\gamma_{2}+\gamma_{3}=1$ and $\gamma_{2}+\gamma_{3}+\gamma_{4}=1$, as well as the Ljung-Box $Q$-statistics of the $10^{\text {th }}$ lag for standard and squared residuals in brackets. $* * *$, **, and $*$ denote significance at 1 per cent, 5 per cent, and 10 per cent, respectively. For clarity of the discussion in the text, coefficients $\mu$ and $\delta$ are multiplied by 100 and $10^{4}$, respectively. 
Table A.4: Estimates of the Effect of the Spot Position to the Target Value on Conditional Volatility (TARCH Models), EU Membership Sub-Sample,

May 2004 to October 2006

\begin{tabular}{|c|c|c|c|c|c|}
\hline Country & Czech Rep. & Hungary & Poland & Slovakia & Romania \\
\hline \multirow[t]{2}{*}{$\mu$} & $-0.032^{* * *}$ & 0.012 & $-0.048^{* *}$ & $-0.027^{* *}$ & -0.016 \\
\hline & $(-2.997)$ & $(0.768)$ & $(-2.339)$ & $(-2.458)$ & $(-1.244)$ \\
\hline \multirow[t]{2}{*}{$\gamma_{1}$} & 0.000 & $0.000^{* *}$ & $0.000^{* *}$ & 0.000 & 0.000 \\
\hline & (1.137) & $(2.080)$ & $(2.256)$ & $(-1.536)$ & $(0.218)$ \\
\hline \multirow[t]{2}{*}{$\gamma_{2}$} & -0.004 & $0.144^{* * *}$ & 0.003 & $0.013^{* *}$ & $0.045^{* * *}$ \\
\hline & $(-0.235)$ & (4.404) & $(0.391)$ & $(2.226)$ & (2.917) \\
\hline \multirow[t]{2}{*}{$\gamma_{3}$} & $0.058^{* *}$ & $-0.152^{* * *}$ & -0.027 & $-0.018^{* * *}$ & $0.212^{* * *}$ \\
\hline & (2.334) & $(-4.176)$ & $(-1.506)$ & $(-2.810)$ & (5.389) \\
\hline \multirow[t]{2}{*}{$\gamma_{4}$} & $0.947^{* * *}$ & $0.893^{* * *}$ & $0.982^{* * *}$ & $0.986^{* * *}$ & $0.844^{* * *}$ \\
\hline & (45.627) & (34.852) & (119.149) & $(217.220)$ & (66.309) \\
\hline \multirow[t]{2}{*}{$\delta_{1}$} & 0.380 & $3.680^{* *}$ & 1.200 & $0.312^{* *}$ & $2.510^{* * *}$ \\
\hline & $(0.883)$ & $(2.363)$ & $(1.640)$ & $(2.479)$ & (6.539) \\
\hline \multirow[t]{2}{*}{$\delta_{2}$} & $4.320^{* * *}$ & -2.030 & $3.760^{* * *}$ & $1.140^{* * *}$ & $5.160^{* * *}$ \\
\hline & $(2.906)$ & $(-1.370)$ & $(3.873)$ & (5.922) & $(5.629)$ \\
\hline \multirow[t]{2}{*}{$\gamma_{2}+\gamma_{3}=1$} & $0.943^{* * *}$ & 1.036 & $0.985^{* *}$ & 0.999 & $0.888^{* * *}$ \\
\hline & {$[0.000]$} & {$[0.106]$} & [0.012] & {$[0.578]$} & {$[0.000]$} \\
\hline \multirow[t]{2}{*}{$\gamma_{2}+\gamma_{3}+\gamma_{4}=1$} & 1.001 & 0.884 & $0.958^{* * *}$ & $0.981^{* * *}$ & $1.100^{* * *}$ \\
\hline & {$[0.961]$} & [0.961] & {$[0.006]$} & {$[0.000]$} & {$[0.000]$} \\
\hline SIC & -8.923 & -8.213 & -7.674 & -9.133 & -8.215 \\
\hline$N$ & 638 & 638 & 638 & 638 & 638 \\
\hline \multirow[t]{2}{*}{ L-B(10), RES } & 17.704 & 16.306 & 13.397 & 12.111 & 4.083 \\
\hline & {$[0.060]$} & [0.091] & {$[0.202]$} & {$[0.278]$} & {$[0.944]$} \\
\hline \multirow[t]{2}{*}{ L-B(10), SQRES } & 15.899 & 14.184 & 10.340 & 9.434 & 2.715 \\
\hline & {$[0.103]$} & {$[0.165]$} & {$[0.411]$} & {$[0.492]$} & [0.987] \\
\hline
\end{tabular}

Notes: We report $z$-stats in parenthesis and p-values of the Wald test that $\gamma_{2}+\gamma_{3}=1$ and $\gamma_{2}+\gamma_{3}+\gamma_{4}=1$, as well as the Ljung-Box $Q$-statistics of the $10^{\text {th }}$ lag for standard and squared residuals in brackets. ***, **, and * denote significance at 1 per cent, 5 per cent, and 10 per cent, respectively. For clarity of the discussion in the text, coefficients $\mu$ and $\delta$ are multiplied by 100 and $10^{4}$, respectively. 
Table A.5: Estimates of the Effect of the Spot Position to the Target Value on Conditional Volatility (EGARCH Models)

\begin{tabular}{|c|c|c|c|c|c|}
\hline Country & Czech Rep. & Hungary & Poland & Slovakia & Romania \\
\hline \multirow[t]{2}{*}{$\mu$} & $-0.021^{* * *}$ & $0.015^{* * *}$ & -0.014 & $-0.011^{*}$ & $0.027^{* * *}$ \\
\hline & $-(3.096)$ & $(2.985)$ & $-(1.117)$ & $-(1.799)$ & $(2.874)$ \\
\hline \multirow[t]{2}{*}{$\gamma_{1}$} & $-0.710^{* * *}$ & $-0.764^{* * *}$ & $-0.604^{* * *}$ & $-1.003^{* * *}$ & $-0.419^{* * *}$ \\
\hline & $-(6.912)$ & $-(19.971)$ & $-(8.302)$ & $-(8.997)$ & $-(10.403)$ \\
\hline \multirow[t]{2}{*}{$\gamma_{2}$} & $0.134^{* * *}$ & $0.225^{* * *}$ & $0.141^{* * *}$ & $0.206^{* * *}$ & $0.232^{* * *}$ \\
\hline & (11.190) & (19.861) & $(8.428)$ & $(12.298)$ & (19.175) \\
\hline \multirow[t]{2}{*}{$\gamma_{3}$} & -0.010 & $0.091^{* * *}$ & $0.081^{* * *}$ & $0.027^{* * *}$ & $-0.039^{* * *}$ \\
\hline & $-(1.128)$ & (10.735) & $(6.525)$ & $(2.673)$ & $-(5.205)$ \\
\hline \multirow[t]{2}{*}{$\gamma_{4}$} & $0.949^{* * *}$ & $0.954^{* * *}$ & $0.954^{* * *}$ & $0.931^{* * *}$ & $0.978^{* * *}$ \\
\hline & (113.836) & (353.735) & (145.001) & (109.500) & $(282.682)$ \\
\hline \multirow[t]{2}{*}{$\delta_{1}$} & $0.935^{* * *}$ & $5.576^{* * *}$ & 0.289 & $1.578^{* * *}$ & $0.499^{* *}$ \\
\hline & $(2.906)$ & (21.582) & (1.404) & $(4.457)$ & $(2.094)$ \\
\hline \multirow[t]{2}{*}{$\delta_{2}$} & $2.799^{* * *}$ & $1.331^{* * *}$ & $1.008^{* * *}$ & $2.578^{* * *}$ & 0.342 \\
\hline & $(6.373)$ & (8.092) & $(5.675)$ & (6.894) & (1.600) \\
\hline SIC & -8.614 & -8.604 & -7.400 & -9.089 & -7.623 \\
\hline$N$ & 2028 & 2028 & 2028 & 2028 & 2028 \\
\hline \multirow[t]{2}{*}{ L-B(10), RES } & 5.983 & 11.674 & $21.848^{* *}$ & 13.888 & 12.486 \\
\hline & {$[0.817]$} & [0.307] & {$[0.016]$} & {$[0.126]$} & {$[0.254]$} \\
\hline \multirow[t]{2}{*}{ L-B(10), SQRES } & 6.453 & 5.007 & $16.936^{*}$ & 5.785 & 9.390 \\
\hline & {$[0.776]$} & [0.891] & {$[0.076]$} & {$[0.761]$} & {$[0.496]$} \\
\hline
\end{tabular}

Notes: We report $z$-statistics in parenthesis and the Ljung-Box $Q$-statistics of the $10^{\text {th }}$ lag for standard and squared residuals in brackets. ${ }^{* *}, * *$, and $*$ denote significance at 1 per cent, 5 per cent, and 10 per cent, respectively. 


\section{CESifo Working Paper Series}

for full list see www.cesifo-group.org/wp

(address: Poschingerstr. 5, 81679 Munich, Germany, office@cesifo.de)

2044 Annika Alexius and Bertil Holmlund, Monetary Policy and Swedish Unemployment Fluctuations, July 2007

2045 Axel Dreher, Jan-Egbert Sturm and Jakob de Haan, Does High Inflation Cause Central Bankers to Lose their Job? Evidence Based on a New Data Set, July 2007

2046 Guglielmo Maria Caporale and Luis A. Gil-Alana, Long Run and Cyclical Dynamics in the US Stock Market, July 2007

2047 Alessandro Balestrino, It is a Theft but not a Crime, July 2007

2048 Daniel Becker and Michael Rauscher, Fiscal Competition in Space and Time: An Endogenous-Growth Approach, July 2007

2049 Yannis M. Ioannides, Henry G. Overman, Esteban Rossi-Hansberg and Kurt Schmidheiny, The Effect of Information and Communication Technologies on Urban Structure, July 2007

2050 Hans-Werner Sinn, Please Bring me the New York Times - On the European Roots of Richard Abel Musgrave, July 2007

2051 Gunther Schnabl and Christian Danne, A Role Model for China? Exchange Rate Flexibility and Monetary Policy in Japan, July 2007

2052 Joseph Plasmans, Jorge Fornero and Tomasz Michalak, A Microfounded Sectoral Model for Open Economies, July 2007

2053 Vesa Kanniainen and Panu Poutvaara, Imperfect Transmission of Tacit Knowledge and other Barriers to Entrepreneurship, July 2007

2054 Marko Koethenbuerger, Federal Tax-Transfer Policy and Intergovernmental PreCommitment, July 2007

2055 Hendrik Jürges and Kerstin Schneider, What Can Go Wrong Will Go Wrong: Birthday Effects and Early Tracking in the German School System, July 2007

2056 Bahram Pesaran and M. Hashem Pesaran, Modelling Volatilities and Conditional Correlations in Futures Markets with a Multivariate t Distribution, July 2007

2057 Walter H. Fisher and Christian Keuschnigg, Pension Reform and Labor Market Incentives, July 2007

2058 Martin Altemeyer-Bartscher, Dirk T. G. Rübbelke and Eytan Sheshinski, Policies to Internalize Reciprocal International Spillovers, July 2007 
2059 Kurt R. Brekke, Astrid L. Grasdal and Tor Helge Holmås, Regulation and Pricing of Pharmaceuticals: Reference Pricing or Price Cap Regulation?, July 2007

2060 Tigran Poghosyan and Jakob de Haan, Interest Rate Linkages in EMU Countries: A Rolling Threshold Vector Error-Correction Approach, July 2007

2061 Robert Dur and Klaas Staal, Local Public Good Provision, Municipal Consolidation, and National Transfers, July 2007

2062 Helge Berger and Anika Holler, What Determines Fiscal Policy? Evidence from German States, July 2007

2063 Ernesto Reuben and Arno Riedl, Public Goods Provision and Sanctioning in Privileged Groups, July 2007

2064 Jan Hanousek, Dana Hajkova and Randall K. Filer, A Rise by Any Other Name? Sensitivity of Growth Regressions to Data Source, July 2007

2065 Yin-Wong Cheung and Xing Wang Qian, Hoarding of International Reserves: Mrs Machlup's Wardrobe and the Joneses, July 2007

2066 Sheilagh Ogilvie, 'Whatever Is, Is Right'?, Economic Institutions in Pre-Industrial Europe (Tawney Lecture 2006), August 2007

2067 Floriana Cerniglia and Laura Pagani, The European Union and the Member States: Which Level of Government Should Do what? An Empirical Analysis of Europeans' Preferences, August 2007

2068 Alessandro Balestrino and Cinzia Ciardi, Social Norms, Cognitive Dissonance and the Timing of Marriage, August 2007

2069 Massimo Bordignon, Exit and Voice. Yardstick versus Fiscal Competition across Governments, August 2007

2070 Emily Blanchard and Gerald Willmann, Political Stasis or Protectionist Rut? Policy Mechanisms for Trade Reform in a Democracy, August 2007

2071 Maarten Bosker and Harry Garretsen, Trade Costs, Market Access and Economic Geography: Why the Empirical Specification of Trade Costs Matters, August 2007

2072 Marco Runkel and Guttorm Schjelderup, The Choice of Apportionment Factors under Formula Apportionment, August 2007

2073 Jay Pil Choi, Tying in Two-Sided Markets with Multi-Homing, August 2007

2074 Marcella Nicolini, Institutions and Offshoring Decision, August 2007

2075 Rainer Niemann, The Impact of Tax Uncertainty on Irreversible Investment, August 2007 
2076 Nikitas Konstantinidis, Gradualism and Uncertainty in International Union Formation, August 2007

2077 Maria Bas and Ivan Ledezma, Market Access and the Evolution of within Plant Productivity in Chile, August 2007

2078 Friedrich Breyer and Stefan Hupfeld, On the Fairness of Early Retirement Provisions, August 2007

2079 Scott Alan Carson, Black and White Labor Market Outcomes in the $19^{\text {th }}$ Century American South, August 2007

2080 Christian Bauer, Paul De Grauwe and Stefan Reitz, Exchange Rates Dynamics in a Target Zone - A Heterogeneous Expectations Approach, August 2007

2081 Ana Rute Cardoso, Miguel Portela, Carla Sá and Fernando Alexandre, Demand for Higher Education Programs: The Impact of the Bologna Process, August 2007

2082 Christian Hopp and Axel Dreher, Do Differences in Institutional and Legal Environments Explain Cross-Country Variations in IPO Underpricing?, August 2007

2083 Hans-Werner Sinn, Pareto Optimality in the Extraction of Fossil Fuels and the Greenhouse Effect: A Note, August 2007

2084 Robert Fenge, Maximilian von Ehrlich and Matthias Wrede, Fiscal Competition, Convergence and Agglomeration, August 2007

2085 Volker Nitsch, Die Another Day: Duration in German Import Trade, August 2007

2086 Kam Ki Tang and Jie Zhang, Morbidity, Mortality, Health Expenditures and Annuitization, August 2007

2087 Hans-Werner Sinn, Public Policies against Global Warming, August 2007

2088 Arti Grover, International Outsourcing and the Supply Side Productivity Determinants, September 2007

2089 M. Alejandra Cattaneo and Stefan C. Wolter, Are the Elderly a Threat to Educational Expenditures?, September 2007

2090 Ted Bergstrom, Rod Garratt and Damien Sheehan-Connor, One Chance in a Million: Altruism and the Bone Marrow Registry, September 2007

2091 Geraldo Cerqueiro, Hans Degryse and Steven Ongena, Rules versus Discretion in Loan Rate Setting, September 2007

2092 Henrik Jacobsen Kleven, Claus Thustrup Kreiner and Emmanuel Saez, The Optimal Income Taxation of Couples as a Multi-Dimensional Screening Problem, September 2007 
2093 Michael Rauber and Heinrich W. Ursprung, Life Cycle and Cohort Productivity in Economic Research: The Case of Germany, September 2007

2094 David B. Audretsch, Oliver Falck and Stephan Heblich, It’s All in Marshall: The Impact of External Economies on Regional Dynamics, September 2007

2095 Michael Binder and Christian J. Offermanns, International Investment Positions and Exchange Rate Dynamics: A Dynamic Panel Analysis, September 2007

2096 Louis N. Christofides and Amy Chen Peng, Real Wage Chronologies, September 2007

2097 Martin Kolmar and Andreas Wagener, Tax Competition with Formula Apportionment: The Interaction between Tax Base and Sharing Mechanism, September 2007

2098 Daniela Treutlein, What actually Happens to EU Directives in the Member States? - A Cross-Country Cross-Sector View on National Transposition Instruments, September 2007

2099 Emmanuel C. Mamatzakis, An Analysis of the Impact of Public Infrastructure on Productivity Performance of Mexican Industry, September 2007

2100 Gunther Schnabl and Andreas Hoffmann, Monetary Policy, Vagabonding Liquidity and Bursting Bubbles in New and Emerging Markets - An Overinvestment View, September 2007

2101 Panu Poutvaara, The Expansion of Higher Education and Time-Consistent Taxation, September 2007

2102 Marko Koethenbuerger and Ben Lockwood, Does Tax Competition Really Promote Growth?, September 2007

2103 M. Hashem Pesaran and Elisa Tosetti, Large Panels with Common Factors and Spatial Correlations, September 2007

2104 Laszlo Goerke and Marco Runkel, Tax Evasion and Competition, September 2007

2105 Scott Alan Carson, Slave Prices, Geography and Insolation in $19^{\text {th }}$ Century AfricanAmerican Stature, September 2007

2106 Wolfram F. Richter, Efficient Tax Policy Ranks Education Higher than Saving, October 2007

2107 Jarko Fidrmuc and Roman Horváth, Volatility of Exchange Rates in Selected New EU Members: Evidence from Daily Data, October 2007 